\title{
THE DIFFERENCES OF INTRUCTIONAL MEDIA AND COORDINATION IN LEARNING OUTCOMES OF GROUNDSTROKES TENNIS ON NOVICE LEVEL ATHLETES
}

\author{
Dian Pujianto* \\ State Universitas of Bengkulu* \\ dianpujianto@unib.ac.id*
}

Abstract

The purpose of this study was to find out the differences in instructional media and coordination to learning outcomes on tennis groundstrokes of novice athletes. This experimental research with $2 \times 3$ of factorial design was conducted in the Bengkulu city, Data was collected through groundstrokes tennis test. The analysis of data outcomes was stated (1) demonstration and video tennis training media gave different learning outcomes of groundstrokes tennis on students. (2) demonstration and tennis video game media gave different learning outcomes of groundstrokes tennis on students. (3) video tennis training and tennis video game media gave different learning outcomes of groundstrokes tennis on students. (4) there were differences in instructional media and coordination skill on learning outcomes of groundstrokes tennis on students. (5) demonstration and video tennis training media gave different learning outcomes of groundstrokes tennis on students with high coordination skill. (6) demonstration and tennis video game media gave different learning outcomes of groundstrokes tennis on students with high coordination skill. (7) no learning outcomes differences of groundstrokes tennis between video tennis training and tennis video game media on students with high coordination skill. (8) no learning outcomes differences of groundstrokes tennis between demonstration and video tennis training media on students with low coordination skill. (9) no learning outcomes differences of groundstrokes tennis between demonstration and tennis video game media on students with low coordination skill. (10) video tennis training and tennis video game media gave different learning outcomes of groundstrokes tennis on students with low coordination skill.The results were recommended that video tennis training media should be used to train the skill of groundstrokes tennis on student with low coordination skill, while demonstration media should be used for novices with high coordination skill.

Keywords : Instructional Media, Coordination, Groundstrokes.

Tennis is including in compulsory courses because it has been considered as one of sports that capable to bring anyone become more sociable, this course also given a place in student activity unit. Difficulties in tennis learning also occur in students of study program of health education and recreation Universitas Bengkulu, despite it should be easier for the students to learn the movement skill. However, in fact students who took tennis course for 1 semester and had joined the tennis student activity still incapable to cope the basic techniques of tennis. Therefore, to be able to cope the technique skills the students need to learn by practice.

Learning is a continuous process. Learning is a permanent outcome which is a result from practice and experience. Wingkel ( $2007: 58$ ) said that learning is a process or a mental activity which is unseen from outside. Learning outcomes, according to Rustam, is a number of experience which have been achieved by student include cognitive, affective and psychomotor aspects (2015: 32 ). Learning outcome is ability that student had been obtained after going through the learning activities, Abdurrahman dalam Jihad, A dan Haris A ( $2013: 14$ ).

In the same way, learn the tennis groundstrokes skill will give the tennis groundstrokes skill as learning outcomes. According to Brown ( 2007 : 31 ) groundstrokes is a blow after the ball bounced in the court, that means groundstrokes can be interpreted as a blow after the ball touches the ground. To be able to do this movement, the athlete must have coordination. Siedentop, D dan Van der Mars, H, ( 2012 : 35 ) stated coordination is the ability to use body parts to perform motor skill smoothly and accurately. From this statement, it can be explained that coordination is the ability to use parts of the body to perform 
motion skills smoothly with good accuracy. However, Instructional media is also required to be able to learn well.

Media is any person, material, tool, or event that can create a condition which can provide an input for learners to receive knowledges, skills, and attitudes, Samsudin ( $2014: 2$ ). Smaldino, Lowther, dan Russell ( $2011: 7$ ) stated media as a plural of medium (intermediaries), as communication tools, the media are classified into six categories, namely text, audio, visual, video, modification, and human. Then, learning is a process of student learning which has been provided by educators and have the basic word "learn". Learning is a relatively permanent change and occurs either directly or indirectly as the result after the learning process is finish, Hergenhanh dan Olson ( 2014 : 2-3). Magill dan Anderson ( 2011 : 257 ) stated that learning: a change in the capability of a person to perform a skill that must be inferred from a relatively permanent improvement in perfomance as a result of practice or experience.

Based on the above description, it is obvious that a learning needs the right media, therefore a study of media in tennis practice learning for novices are needed.

In the previous research, Sukadiyanto had been investigated open and closed learning model on novices with high and low coordination. The results showed that novices with high coordination more dominate forehand and backhand groundstroke techniques compare to novices with low coordination. Therefore, this study will focus on the differences instructional media and coordination to groundstrokes practice on novices.

In general, this research is conduct to know the differences of instructional media and coordination to groundstrokes practice on novices.

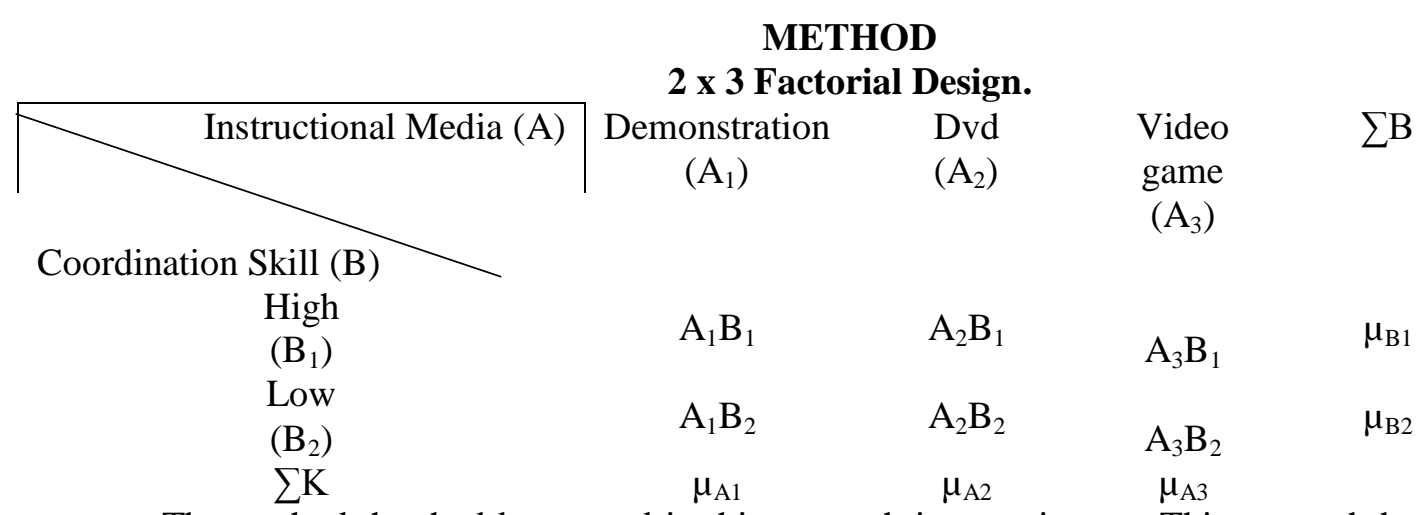

The method that had been used in this research is experiment. This research has groundstrokes learning outcome as dependent variable. While treatment using demonstration, video tennis training, and tennis video game as free variable, in addition coordination skill as attribute-free variable.

Population has been represented by sample. Based on this opinion, the sample in this research is students on the second and fourth semester. Sampling is done gradually:

a. Purposively, selecting Universitas Bengkulu as the place for experiment.

b. Randomly, determining treatment groups by using human, video tennis training, and tennis video game which are given on second and fourth semester in A or B group along with one group as instrument test group. The determination instructional media usage and instrument test group is done by lottery.

The next step is collecting data using instrument. The instrument in this study is test. The test was used to measure the student learning outcome in this study is Hewitt groundstrokes test. The data of each student has been collected in the end of class with groundstrokes test by hit a ball to target, the score is accumulated from 10 times trial. In addition, another instrument test is performed by modification of tennis ball throw test to measure the coordination skill of the student. Two way Anova is used as a technique to analyze the data. Normality and variant homogeneity tests is done as preliminary test and Tukey test is done after Anova test.

\section{RESULT AND DISCUSSION}


The result, in Table 1, showed that there are differences instructional media usage to tennis groundstrokes skill of students or novice athletes. Also, there is an influence from the interaction between instructional media and coordination skill.

Table.1. Hypothesis Testing of Differences Instructional Media and Effect of Interaction of Tennis Groundstrokes Learning Outcomes.

Tests of Between-Subjects Effects

Dependent Variable:HG

\begin{tabular}{|l|r|r|r|r|r|}
\hline Source & $\begin{array}{c}\text { Type III Sum of } \\
\text { Squares }\end{array}$ & $d f$ & Mean Square & \multicolumn{1}{c|}{$F$} & \multicolumn{1}{c|}{ Sig. } \\
\hline Corrected Model & 300.987 & 5 & 60.197 & 10.633 & .000 \\
Intercept & 13455.038 & 1 & 13455.038 & $2.377 \mathrm{E} 3$ & .000 \\
MP & 180.625 & 2 & 90.313 & 15.952 & .000 \\
Koor & 75.938 & 1 & 75.938 & 13.413 & .001 \\
MP $*$ Koor & 44.425 & 2 & 22.212 & 3.923 & .026 \\
Error & 305.725 & 54 & 5.662 & & \\
Total & 14061.750 & 60 & & & \\
Corrected Total & 606.712 & 59 & & & \\
\hline
\end{tabular}

a. $\quad$ R Squared $=, 496$ (Adjusted R Squared $=, 449)$

a. Testing of First Hypothesis, Differences of demonstration and video tennis training media on tennis groundstrokes learning outcome of students. (A1)(A2)

Table.2. Hypothesis Testing of Differences Instructional Media on Tennis Groundstrokes Learning Outcomes.

HG

Multiple Comparisons

\begin{tabular}{|c|c|c|c|c|c|c|}
\hline \multirow[b]{2}{*}{ (I) MP } & \multirow[b]{2}{*}{ (J) MP } & \multirow{2}{*}{$\begin{array}{c}\text { Mean } \\
\text { Difference } \\
(\mathrm{I}-\mathrm{J})\end{array}$} & \multirow[b]{2}{*}{ Std. Error } & \multirow[b]{2}{*}{ Sig. } & \multicolumn{2}{|c|}{$\begin{array}{l}\text { 95\% Confidence } \\
\text { Interval }\end{array}$} \\
\hline & & & & & $\begin{array}{l}\text { Lower } \\
\text { Bound }\end{array}$ & $\begin{array}{l}\text { Upper } \\
\text { Bound }\end{array}$ \\
\hline \multirow[t]{2}{*}{$\begin{array}{l}\text { Demonstras } \\
\text { tion Media }\end{array}$} & $\begin{array}{l}\text { Video Tennis } \\
\text { Training } \\
\text { Media }\end{array}$ & $2.1250^{*}$ & .86459 & .044 & .0444 & 4.2056 \\
\hline & $\begin{array}{l}\text { Tennis Video } \\
\text { Game Media }\end{array}$ & $4.2500^{*}$ & .86459 & .000 & 2.1694 & 6.3306 \\
\hline \multirow{2}{*}{$\begin{array}{l}\text { Video } \\
\text { Tennis } \\
\text { Training } \\
\text { Media }\end{array}$} & $\begin{array}{l}\text { Demonstrastio } \\
\text { n Media }\end{array}$ & $-2.1250^{*}$ & .86459 & .044 & -4.2056 & -.0444 \\
\hline & $\begin{array}{l}\text { Tennis Video } \\
\text { Game Media }\end{array}$ & $2.1250^{*}$ & .86459 & .044 & .0444 & 4.2056 \\
\hline $\begin{array}{l}\text { Tennis } \\
\text { Video }\end{array}$ & $\begin{array}{l}\text { Demonstrastio } \\
\text { n Media }\end{array}$ & $-4.2500^{*}$ & .86459 & .000 & -6.3306 & -2.1694 \\
\hline
\end{tabular}




\begin{tabular}{|c|c|c|c|c|c|c|}
\hline $\begin{array}{l}\text { Game } \\
\text { Media }\end{array}$ & $\begin{array}{l}\text { Video Tennis } \\
\text { Training } \\
\text { Media }\end{array}$ & $-2.1250^{*}$ & .86459 & .044 & -4.2056 & -.0444 \\
\hline
\end{tabular}

*. The mean difference is significant at the, 05 level.

Based on the results of hypothesis test on Table 2, the calculation result is showed the differences of demonstration and video tennis training media on tennis groundstrokes learning outcomes of students. The calculation also give the coefficient value as 0.044 , this value is then compare with a significance level of 0.05 .

The coefficient value of hypothesis testing as 0.044 which is smaller than the significance level of 0.05 , therefore it can be concluded that $\mathrm{H}_{\mathrm{o}}$ is rejected while $\mathrm{H}_{1}$ is accepted. Generally, both instructional medias have had different or significant impact on tennis groundstrokes learning outcomes of students. In which demonstration media give better impact than video tennis training media.

b. Testing of Second Hypothesis, Differences of demonstration and tennis video game media on tennis groundstrokes learning outcome of students. (A1)(A3)

Based on the results of hypothesis test on Table 2, the result is showed the differences of demonstration and tennis video game media on tennis groundstrokes learning outcomes of students. The result give the coefficient value as 0.000 and compare with a significance level of 0.05 .

The comparison showed that the result of hypothesis testing give smaller value that the significance level, therefore it can be stated that $\mathrm{H}_{\mathrm{o}}$ is rejected and $\mathrm{H}_{1}$ is accepted. In general, both of these instructional medias have had different or significant impact on tennis groundstrokes learning outcomes of students, where demonstration media give the real movement compare to tennis video game media. Hence it gives better impact in the learning process.

\section{c. Testing of Third Hypothesis, Differences of video tennis training and tennis video game media on tennis groundstrokes learning outcome of students. (A2)(A3)}

According to Table 2, the calculation of the result of hypothesis testing is indicated the differences of video tennis training and tennis video game media on tennis groundstrokes learning outcomes of students. The coefficient value of 0.044 is obtained from the calculation, this value is then compare with a significance level of 0.05 .

The calculation give smaller value compare to the significance level, in this case, $\mathrm{H}_{\mathrm{o}}$ is rejected while $\mathrm{H}_{1}$ is accepted. Both instructional medias have had different or significant impact on tennis groundstrokes learning outcomes of students. Based on this test it is obvious that both instructional media give different influence to tennis groundstrokes learning outcomes of students. It is because video tennis training provides a more realistic model motion than tennis video game. Tennis video game media is a manmade media that resemble to human movement on tennis and this movement is abstract therefore it tends to be more difficult to learn than video tennis training media which is a recording of learning process.

\section{d. Testing of Fourth Hypothesis, Interaction between Instructional Media and Coordination Skill to Tennis Groundstrokes Learning Outcomes. (A x B)}

Based on the result of hypothesis testing on Table 1, the coordination difference test give coefficient value as 0.001 which is compare to the significance value of 0.05 . It turns out the coefficient value is smaller than significance value. Thus, it can be concluded that there is significant difference between tennis groundstrokes learning outcomes of student with high coordination skill and student with low coordination skill. This result suggests the most appropriate instructional media for each group that teachers or trainers can consider to use based on the coordination skill of students.

The calculation result for fourth hypothesis also shows in Table 1, which is the interaction between instructional media and coordination skill on groundstrokes learning outcomes. The coefficient value for this calculation is 0.026 which is smaller than the significance value of 0.05 . In this case $\mathrm{H}_{\mathrm{o}}$ is 
rejected while $\mathrm{H}_{1}$ is accepted, this is indicating the effect of interaction between instructional media and coordination skill on tennis groundstrokes learning outcomes of students.

Due to the number of sample is exactly the same, the test is followed by Tukey test. This test is done to know the differences of groundstrokes learning outcomes for each group. Therefore, the next step is differences test between each group.

e. Testing of Fifth Hypothesis, Differences of demonstration and video tennis training media on tennis groundstrokes learning outcome of student with high coordination. (A1B1) (A2B1)

Below is the result of Tukey test, as presented in Table 3. The calculation result is compare to significance level of 0.05 .

Table.3. The Result of Tukey Test on Groundstrokes Learning Outcomes

\begin{tabular}{|c|c|c|c|c|c|c|}
\hline \multirow{2}{*}{$\begin{array}{l}\text { (I) } \\
\text { KLMP } \\
\text { K }\end{array}$} & \multirow{2}{*}{$\begin{array}{l}\text { (J) } \\
\text { KLMPK }\end{array}$} & \multirow{2}{*}{$\begin{array}{c}\text { Mean } \\
\text { Difference (I- } \\
\mathrm{J})\end{array}$} & \multirow[b]{2}{*}{ Std. Error } & \multirow[b]{2}{*}{ Sig. } & \multicolumn{2}{|c|}{$\begin{array}{l}\text { 95\% Confidence } \\
\text { Interval }\end{array}$} \\
\hline & & & & & $\begin{array}{l}\text { Lower } \\
\text { Bound }\end{array}$ & $\begin{array}{l}\text { Upper } \\
\text { Bound }\end{array}$ \\
\hline \multirow[t]{5}{*}{ A1B1 } & $\mathrm{A} 2 \mathrm{~B} 1$ & $3.30000^{*}$ & 1.06654 & .035 & .1489 & 6.4511 \\
\hline & A3B1 & $4.30000^{*}$ & 1.06654 & .002 & 1.1489 & 7.4511 \\
\hline & $\mathrm{A} 1 \mathrm{~B} 2$ & $4.50000^{*}$ & 1.06654 & .001 & 1.3489 & 7.6511 \\
\hline & $\mathrm{A} 2 \mathrm{~B} 2$ & $3.45000^{*}$ & 1.06654 & .024 & .2989 & 6.6011 \\
\hline & A3B2 & $6.90000^{*}$ & 1.06654 & .000 & 3.7489 & 10.0511 \\
\hline \multirow[t]{5}{*}{ A2B1 } & A1B1 & $-3.30000^{*}$ & 1.06654 & .035 & -6.4511 & -.1489 \\
\hline & A3B1 & 1.00000 & 1.06654 & .935 & -2.1511 & 4.1511 \\
\hline & A1B2 & 1.20000 & 1.06654 & .869 & -1.9511 & 4.3511 \\
\hline & $\mathrm{A} 2 \mathrm{~B} 2$ & .15000 & 1.06654 & 1.000 & -3.0011 & 3.3011 \\
\hline & $\mathrm{A} 3 \mathrm{~B} 2$ & $3.60000^{*}$ & 1.06654 & .016 & .4489 & 6.7511 \\
\hline \multirow[t]{5}{*}{ A3B1 } & $\mathrm{A} 1 \mathrm{~B} 1$ & $-4.30000^{*}$ & 1.06654 & .002 & -7.4511 & -1.1489 \\
\hline & $\mathrm{A} 2 \mathrm{~B} 1$ & -1.00000 & 1.06654 & .935 & -4.1511 & 2.1511 \\
\hline & $\mathrm{A} 1 \mathrm{~B} 2$ & .20000 & 1.06654 & 1.000 & -2.9511 & 3.3511 \\
\hline & $\mathrm{A} 2 \mathrm{~B} 2$ & -.85000 & 1.06654 & .967 & -4.0011 & 2.3011 \\
\hline & A3B2 & 2.60000 & 1.06654 & .162 & -.5511 & 5.7511 \\
\hline \multirow[t]{5}{*}{ A1B2 } & $\mathrm{A} 1 \mathrm{~B} 1$ & $-4.50000^{*}$ & 1.06654 & .001 & -7.6511 & -1.3489 \\
\hline & A2B1 & -1.20000 & 1.06654 & .869 & -4.3511 & 1.9511 \\
\hline & A3B1 & -.20000 & 1.06654 & 1.000 & -3.3511 & 2.9511 \\
\hline & $\mathrm{A} 2 \mathrm{~B} 2$ & -1.05000 & 1.06654 & .921 & -4.2011 & 2.1011 \\
\hline & A3B2 & 2.40000 & 1.06654 & .233 & -.7511 & 5.5511 \\
\hline \multirow[t]{5}{*}{$\mathrm{A} 2 \mathrm{~B} 2$} & A1B1 & $-3.45000^{*}$ & 1.06654 & .024 & -6.6011 & -.2989 \\
\hline & $\mathrm{A} 2 \mathrm{~B} 1$ & -.15000 & 1.06654 & 1.000 & -3.3011 & 3.0011 \\
\hline & A3B1 & .85000 & 1.06654 & .967 & -2.3011 & 4.0011 \\
\hline & A1B2 & 1.05000 & 1.06654 & .921 & -2.1011 & 4.2011 \\
\hline & A3B2 & $3.45000^{*}$ & 1.06654 & .024 & .2989 & 6.6011 \\
\hline A3B2 & A1B1 & $-6.90000^{*}$ & 1.06654 & .000 & -10.0511 & -3.7489 \\
\hline
\end{tabular}




\begin{tabular}{|r|r|r|r|r|r|}
\hline A2B1 & $-3.60000^{*}$ & 1.06654 & .016 & -6.7511 & -.4489 \\
A3B1 & -2.60000 & 1.06654 & .162 & -5.7511 & .5511 \\
A1B2 & -2.40000 & 1.06654 & .233 & -5.5511 & .7511 \\
A2B2 & $-3.45000^{*}$ & 1.06654 & .024 & -6.6011 & -.2989 \\
\hline
\end{tabular}

*. The mean difference is significant at the 0.05 level.

According to Tukey test above, A1B1 and A2B1 groups give coefficient value of 0.035 . Compare to the significance value of 0.05 . this result is indicating that $\mathrm{H}_{\mathrm{o}}$ is rejected while $\mathrm{H}_{1}$ is accepted. Hence, there is differences in the use of demonstration and video tennis training media on tennis groundstrokes learning outcome of student with high coordination.

f. Testing of Sixth Hypothesis, Differences of demonstration and tennis video game media on tennis groundstrokes learning outcome of student with high coordination. (A1B1) (A3B1)

The Tukey test result give coefficient value as 0.002 for A1B1 and A3B1 groups. This value is smaller than the significance value of 0.05 and indicate that $\mathrm{H}_{\mathrm{o}}$ is rejected while $\mathrm{H}_{1}$ is accepted. Based on the comparison result, there is differences of demonstration and tennis video game media usage on tennis groundstrokes learning outcome of student with high coordination.

g. Testing of Seventh Hypothesis, Differences of video tennis training and tennis video game media on tennis groundstrokes learning outcome of student with high coordination. (A2B1) (A3B1)

According to Tukey test result between A2B1 and A3B1 above, it gives the coefficient value as 0.935. This value is bigger that the significance value of 0.05 . Therefore, it can be concluded that $\mathrm{H}_{\mathrm{o}}$ is accepted while $\mathrm{H}_{1}$ is rejected and no differences of the use of video tennis training and tennis video game media on groundstrokes learning outcomes of student with high coordination.

h. Testing of Eighth Hypothesis, Differences of demonstration and video tennis training media on tennis groundstrokes learning outcome of student with low coordination. (A1B2) (A2B2)

The coefficient value for A1B2 and A2B2 groups in Tukey test is 0,921 . With a bigger value than significance value of 0.05 , it can be stated that $\mathrm{H}_{\mathrm{o}}$ is accepted while $\mathrm{H}_{1}$ is rejected. Therefore, no differences of the use of demonstration and video tennis training media on groundstrokes learning outcomes of student with low coordination.

i. Testing of Ninth Hypothesis, Differences of demonstration and tennis video game media on tennis groundstrokes learning outcome of student with low coordination. (A1B2) (A3B2)

The coefficient value for A1B2 and A3B2 groups in Tukey test as 0,233 which is bigger value than significance value of 0.05 . Hence, $\mathrm{H}_{\mathrm{o}}$ is accepted while $\mathrm{H}_{1}$ is rejected. It can be concluded that there is no difference of the use of demonstration and tennis video game media on groundstrokes learning outcomes of student with low coordination.

j. Testing of Tenth Hypothesis, Differences of video tennis training and tennis video game media on tennis groundstrokes learning outcome of student with low coordination. (A2B2) (A3B2)

Based on Tukey test result as shows in Table 1, the coefficient value of 0.024 is given from A2B2 and $\mathrm{A} 3 \mathrm{~B} 2$ groups. Compare to the significance value $0 \mathrm{f} 0.05$, this value is smaller. Hence, $\mathrm{H}_{\mathrm{o}}$ is rejected and $\mathrm{H}_{1}$ is accepted. It is show that there is difference of video tennis training and tennis video game on tennis groundstrokes learning outcome of students with low coordination.

\section{CONCLUSION}

According to the results of hypothesis testing, it can be concluded that:

Demonstration and video tennis training media gave different tennis groundstrokes learning outcomes on students. Demonstration and tennis video game media gave different tennis groundstrokes learning 
outcomes on students.Video tennis training and tennis video game media gave different tennis groundstrokes learning outcomes on students. There is an interaction between instructional media and coordination skill on tennis groundstrokes learning outcomes of students. Demonstration and video tennis training media gave different tennis groundstrokes learning outcomes on students with high coordination skill. Demonstration and tennis video game media gave different tennis groundstrokes learning outcomes on students with high coordination skill. No difference between video tennis training and tennis video game media on tennis groundstrokes learning outcomes of students with high coordination skill. No difference between demonstration and video tennis training media on tennis groundstrokes learning outcomes of students with low coordination skill. No difference between demonstration and tennis video game media on tennis groundstrokes learning outcomes of students with low coordination skill. There is difference between video tennis training and tennis video game media on tennis groundstrokes learning outcomes of students with low coordination skill.

\section{REFERENCES}

Brown.J., Tenis Tingkat Pemula. Jakarta : Raja Grafindo, 2007.

Hergenhahn, Olson, Theories of Learning, USA : Pearson, 2014.

Jihad, A. dan Haris, A. Evaluasi Pembelajaran. Yogyakarta : Multi Presindo, 2013.

Magill, R.A., Motor Learning and Control, Concept and Applications. New York:McGraw-Hill.2011.

Rustam. Pembelajaran Tematik Terpadu, Teori, Praktik dan Penilaian. Jakarta : Raja Grafindo, 2015.

Samsudin, Media Pembelajaran Pendidikan Jasmani. Jakarta : LITERA, 2014.

Sharon E. Smaldino, Deborah L. Lowther, James D. Russell, Intructional Tecnology \& Media for

Learning. USA : Pearson, 2011.

Siedentop,D. and Hans van der Mars, Intruduction to Physical Education, Fitness, and Sport. Singapore : McGrawHill, 2012.

Wingkel W.S. Psikologi Pengajaran.Yogyakarta: Media Abadi, 2007 